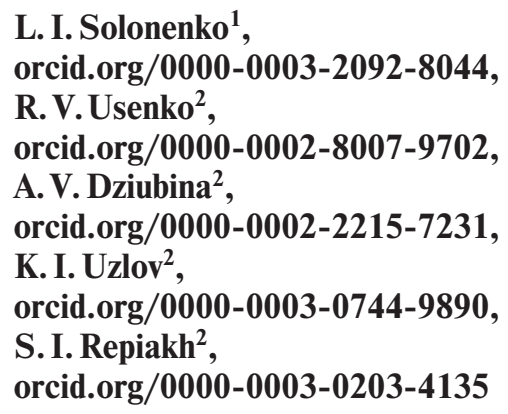

\title{
SODIUM SILICATE SOLUTE FOAMING IN A FLAT SLOT-TYPE CAPILLARY UNDER MICROWAVE RADIATION INFLUENCE
}

Purpose. A mass transferring mechanism during liquid glass foaming in flat slot-type capillary under microwave radiation influence has been determined.

Methodology. Sodium soda silicate solute with silicate module of $2.8-3.0$ and specific gravity of $1.43-1.46 \mathrm{~g} / \mathrm{cm}^{3}$ is used in the studies. For sodium silicate solute coloring, red ink is added. Treatment of sodium silicate solute water solution with microwave radiation is carried out in a furnace with a working chamber volume of 23 liters, with nominal magnetron power of $700 \mathrm{~W}$ and radiation frequency of $2450 \mathrm{MHz}$. Investigation of the structure of foamed sodium silicate solute is done by the optical microscopy method with magnifications of 25 to 200 times. Microwave furnace internal temperature is measured using non-contact electronic infrared thermometer Temperature AR 320. Mass determination is carried out on electronic balance with $0.01 \mathrm{~g}$ accuracy. Liquid glass foaming is organized in a flat slot-type capillary with thickness of 30 to $900 \mu \mathrm{m}$ formed by two glass plates parallel to each other.

Findings. A mechanism of sodium silicate solute mass transferring during its foaming in a flat slot-type capillary when heated by microwave radiation description is developed. It is established that sodium silicate solute transferring in a capillary proceeds in stages according to a scheme similar to a chain reaction. The scheme includes: sodium silicate solute self-encapsulation due to appearance of shell on free surface of partially dehydrated sodium silicate solute; vapor bubble in capsule formation; increasing steam pressure in capsule; capsule shell destruction and ejection of part of unhardened sodium silicate solute out of the capsule; complete removal of sodium silicate solute from the capsule and its destruction under high vapor pressure influence; movement finalization of stream of sodium silicate solute ejected outside the capsule, its repeated self-encapsulation, and so on. This process repeats until water removal from the treated sodium silicate solute will be completed. Sodium silicate solute foam structure formation staging and certain cyclical nature under microwave radiation effects is the main cause of substantial no uniformity of pore dispersion and resulting foam permeability.

Originality. For the first time, description of a mechanism of mass transferring of sodium silicate solute foamed in a flat slottype capillary when heated by microwave radiation has been developed. For the first time it has been determined that sodium silicate solute with silica modulus of 2.8 to 3.0 microwave radiation processing allows reducing water content in dried sodium silicate solute to value less than $0.1 \%$ (wt.).

Practical value. Sodium silicate solute foaming by microwave radiation is a perspective process from the point of view of developing new methods and approaches for solving the problem of optimization of granular material structuring and, in particular, for manufacturing molds and cores. Understanding of sodium silicate solute foaming mechanism will allow increasing the accuracy of predicting the structure of foams produced on sodium silicate solute basis and properties, optimizing the process parameters for their pores formation, expanding the knowledge concerning technological possibilities of implementing sodium silicate solute in porous environments structuring, dehydration by microwave radiation, and so on.

Keywords: mass transferring, vapor, sodium silicate solute, water, capillary, capsule, foaming, microwave radiation

Introduction. Foam is macro-structural state of liquid or solid, unique properties of which allow using foam in:

- geology for conditioning and prevention of subsidence of soil, dressing of ores and minerals;

- engineering - as industrial fluids, sealant, filters, and so on;

- construction - for aerated concrete, foam concrete, expanded clay creation, when performing installation work, in lightweight refractory and heat-insulating materials production (foam-chamotte, expanded vermiculite, perlite, clay, and others) $[1,2]$, porous aggregates [3];

- ecology - absorbers of oil and oil products [4];

- consumer products - foaming glasses $[5,6]$, glass-ceramic foams [7], cement aggregates fillers [6], metal foams [8], adiabatic foams [9], cinder glasses [10];

- foundries - casting molds, rods, ceramic foam filters manufacturing, and so on.

Foam is usually characterized by its multiplicity, stability and dispersion.

(c) Solonenko L.I., Usenko R.V., Dziubina A.V., Uzlov K. I., Repiakh S. I., 2020
Dispersion is one of the most important indicators of any foam. It is present in the form of bubbles' average diameter value or bubble size distribution, or value of bubbles' surface area per foam unit volume.

The size (diameter) of foam bubbles will be identical if their appearance takes place at fixed time conditions.

One of such cases, for example, is the process of foaming with using a capillary immersed within the fluid at constant depth. In this case, regardless of duration of gas purging through the capillary, each foam bubble's diameter will be determined by the volume (and, therefore, bubble diameter) at the time of its separation from the capillary

$$
d=\sqrt[3]{\frac{6 \cdot d_{k} \cdot \sigma}{g \cdot\left(\rho_{2}-\rho_{1}\right)}},
$$

where $d_{k}$ is capillary diameter; $\sigma$ is liquid tension; g is gravity acceleration $\left(9.81 \mathrm{~m} / \mathrm{s}^{2}\right) ; \rho_{2}, \rho_{1}$ are liquid and gas density, respectively.

In other cases, the foam is formed, for example, under condition of a "decaying" chemical reaction. As a result, such 
foam bubbles are characterized by extreme irregularity in size and their diameters in the first approximation from relative time of gas releasing can be calculated in particular according to the formula

$$
d=Z \cdot\left(\frac{1}{\tau}-1\right)
$$

where $\tau$ is relative time of gas releasing in liquid (relative time of chemical reaction duration); $Z$ is the coefficient of proportionality.

For cases described above, kinetics of relative diameter changes of foam bubbles vs. duration of gas releasing in liquid during foaming can be represented in the form of dependencies in Fig. 1, where 1 is foam formed as a result of water blowing with air through a capillary, 2 is foam formed as a result of carbon dioxide releasing by chemical reaction.

Foam dispersion largely determines physical and technological properties of the foam itself and product properties in which it is or in formation of which it has been involved [11]. That is, to predict materials properties in the process of formation of which foaming has been used, it is important to know the mechanism of foam formation while for unbound capillary-porous substance it is important to know the mechanism of its transfer in such medium as well.

One of inorganic materials commonly used in foamed condition, is aqueous sodium silicate (sodium silicate solute). Foamed sodium silicate solute (SSS) has been used in variety industries branches, including that as a binder material in foundry production as environmentally safe and inexpensive sand mixture component [12, 13]. However, SSS, as a material which can be foamed and solidified upon microwave radiation in fine-grained unbound substance, has been insufficiently studied. As a result, SSS potential in this capacity is not fully discovered and such materials' technological, physical and consumer possibilities have not been investigated, and so on. One reason for this is lack of systematic research studies and, consequently, information about technological possibilities and technology of SSS foaming, fragmentation of such data and lack of information concerning regularities and mass transferring mechanism during SSS foaming in fine-grained materials' capillaries under influence of microwave radiation.

Literature review. According to modern concepts and research results by Lazarev A. N. (1965), Brekhunetz A. G. with colleagues (1969), Kazantsev L. K. and Paukshtis E.A. (2002), SSS foaming process with external intensive heating involves two stages. At the first stage, as a result of partial dehydration (free water evaporation) or carbonization - on the surface of heated SSS, respectively, gas-resistant, elastic-plastic SSS layer (elastic shell) or silica-gel appears. At the second stage, heating leads to the fact that SSS, being shut in such shell, is foaming as a result of water vapor formation therein. In this

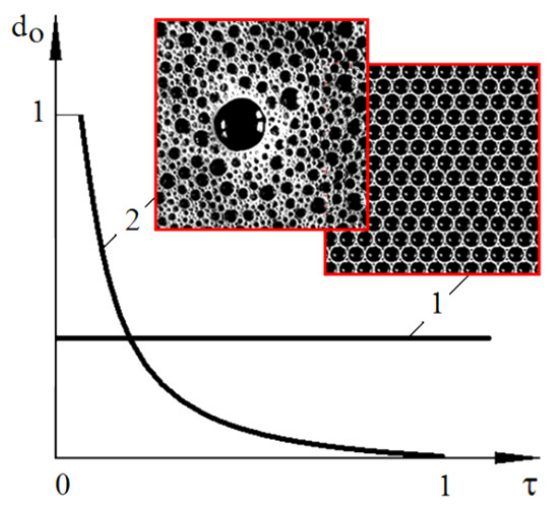

Fig. 1. Dependences of formed foam bubbles' relative diameter on duration of gas releasing in liquid and foam formed by water blown with air through the capillary (1) and carbon dioxide releasing by chemical reaction (2) case, in fact, the outer elastic shells of SSS drops fill with water vapor bubbles emerging in sodium silicate solute. They increase in volume and form closed type pores in hardened SSS. According to various researchers, foaming takes place directly before or after SSS transition in pyroplastic condition, and shell elasticity, thus, has decisive influence on process and degree (multiplicity) of SSS foaming. Grigoriev P. N. and Matveev M.A. (1956), Ryzhkov I. V. (1975), Toturbiev B.D. (1988), Generalov B.V. (1999) and several other researchers believe that the greatest number of pores during SSS foaming by thermal influence are formed at $120-350{ }^{\circ} \mathrm{C}$, i.e. at temperatures when silicate alkaline solutions' pyroplasticity is most obvious and when free and adsorbed water deletes most fully from them.

According to Ryzhkov I.V. (1975) data, SSS heating to $100{ }^{\circ} \mathrm{C}$ leads to free water evaporation and its increasing viscosity. When residual water content is $30-35 \%$, SSS is solidifying according to coagulation mechanism and its further heating is followed by bound water evaporation and SSS transition in pyroplastic condition. SSS pyroplastic state is characterized by occurring hydrated sodium silicate elasticity. Low steam permeability of pyroplastic SSS in combination with its elasticity leads to the fact that at $200-300{ }^{\circ} \mathrm{C}$, crystallization and constitutional water evaporation are accompanied by SSS foaming. Malyawski N.I. (2006) notes that any technological additive previously entered into SSS definitely influence the character of original SSS properties change and foamed material properties. In particular, Kutugin V.A. (2008), found that using chemical substance solutions in quantity exceeding $4 \%$ (wt.) of sodium silicate solute leads to significant decrease in its porization abilities. At the same time, solid insoluble finely dispersed technological additives have no noticeable effect on sodium silicate solute porization. At the same time, increasing crystallinity degree of inter-porous cuffs raises porous structure strength and increases its water resistance. In SSS foaming process, Kutugin V.A. (2008) distinguishes two stages. The first one involves rupture of hydrogen bonds at $100-120{ }^{\circ} \mathrm{C}$ with activation energy of $E_{A}=15-30 \mathrm{~kJ} / \mathrm{mol}$. At the second stage, according to Kutugin V.A. (2008), hydrated sodium silicate viscous flowing is the dominant mechanism, which takes place at $120-400{ }^{\circ} \mathrm{C}$ with activation energy of $E_{A}=40-100 \mathrm{~kJ} / \mathrm{mol}$. Chemically bound water, according to Korneev V.I. and Danilov V. V. (1996), completely removes from SSS crystalline hydrates and hydrates at temperatures close to $600{ }^{\circ} \mathrm{C}$ and also is the reason of its slight foaming. Leonovich $\mathrm{S}$. N. with his collaborators (2012) pointed to two consistent actions in SSS with additions pore formation process - emergence of bubbles mixture in raw water vapor and pyroplastic compounds vitrifying around these bubbles with inter-porous cuffs formation and porous structure fixing. At the same time, slow heating of raw mixture leads to appearance of small pores in it, quick heating - to large pores due to mixture boiling with lag.

The above descriptions of SSS foaming mechanisms are acceptable for processes analysis of droplets in suspension state located in SSS foaming or on open surface in the case of heat from their free surface supplying. Conditions of mass transferring in a capillary under the action of microwave radiation differ significantly from the drop state described above, which has not been studied yet and, accordingly, does not have corresponding description.

Purpose. The purpose of this work was to study the mechanism of mass transferring during sodium silicate solute foaming in a flat slot-type capillary under the action of microwave radiation.

Methods and materials. In these studies, sodium soda SSS (GOST 13078-81) with silicate modulus of 2.8-3.0 and specific gravity of $1.43-1.46 \mathrm{~g} / \mathrm{cm}^{3}$ was used. For SSS coloring red ink has been given. Aqueous SSS solutions were treated with MWR in furnace with a working chamber volume of 23 liters, with rated magnetron power of $700 \mathrm{~W}$ and of $2450 \mathrm{MHz}$ radiation frequency. 
The effect of SSS drying under microwave radiation influence on amount of residual moisture was evaluated by weighing of silicate blocks weights before and after drying in MWR furnace. For this aim, a sample of ash-like silicate block weighing $50-55 \mathrm{~g}$ was used. It had been previously weighed with an accuracy of $0.01 \mathrm{~g}$ and placed in porcelain container of known mass. Then $100-105 \mathrm{~g}$ of distilled water was added to the weighed silicate block in the porcelain container. The silicate block was completely dissolved in water at temperature of $70-80{ }^{\circ} \mathrm{C}$. From prepared solution, a sample weighing $50-$ $70 \mathrm{~g}$ was taken. The obtained SSS was evaporated at $95-97^{\circ} \mathrm{C}$ to viscous-fluid state and treated (dried) with microwave radiation during 20-25 min. Upon completion of drying, the container with dry residue was re-weighed and relative residual moisture content in the sample was calculated with a relative error of $\pm 0.02 \%$.

Based on similarity conditions, the process of water evaporation from capillary space of granular material wetted by water and liquid transfer in it was investigated in an infinite flat slot-type capillary. For this, two glass plates were used, between which an SSS drop was placed. The distance between plates positioned in parallel (capillary channel thickness) was ranged from 30 to $1000 \mu \mathrm{m}$. For processing by microwave radiation, the plates were placed in horizontal position in the center of the rotating table of the MWR furnace. The processing time of SSS treatment by microwave radiation was from 10 to $90 \mathrm{sec}$. At the end of the treatment, the plates were cooled in air, thickness of flat capillary was determined and plates were separated mechanically from each other. The structures of solid substances formed in the slot capillary (silicate, metasilicate) were studied using a binocular microscope with magnifications of 25 to 200 times. To measure the objects' temperature in the microwave furnace, an industrial non-contact electronic infrared thermometer Temperature AR 320 was used.

Results. Based on the visual assessment results of the structure of the SSS solidified in the flat slot-type capillary of $h=$ $=30 \mu \mathrm{m}$, it was found that in the initial period of microwave radiation treatment on free surface of unsolidified SSS, due to water evaporation from its surface layer (open surface), continuous elastic shell 1 of partially dehydrated SSS appears. It follows from the SSS droplet structure analysis presented in Fig. 2.

Inside the shell 1 , there is an uncured SSS 2 , in the center of which from the side of glasses forming a flat capillary, there is a colony of poly silicate crystals 3. Apparently, observed poly silicate crystals (Fig. 2), in accordance with study results by Ailer R. (1982) and Malyawski N. I. (1985, 2003) and several other researchers, are presented by polymer structures of silicon-oxygen anions, of which, according to Krasovsky A. N. and his team (1989), when heated to the temperature up to $157{ }^{\circ} \mathrm{C}$, molecular water strongly bound by hydrogen bonds with poly anions releases.

With relatively large droplet sizes of the initial SSS, incompletely solidified SSS in flat capillaries with thickness $h$ of 50 to

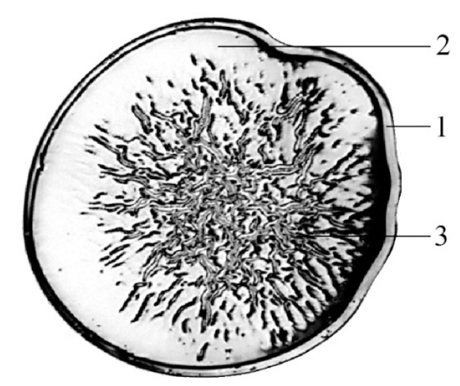

Fig. 2. Appearance of the SSS droplet free surface $(\times 25)$ in a flat slot-type capillary at the initial stage of MWR treatment:

1 - film (outer surface) of SSS dehydrated shell; 2 - sodium silicate aqueous solution; 3 - colony of solid silicate substances
$350 \mu \mathrm{m}$ is a two-dimensional foam structure with flat open gas bubbles. Such a structure in terms of the area in a plan exceeds the area of the initial SSS drop by more than 40 times and consists of alternating voids and volumes with unsolidified SSS, which is shown schematically in Fig. 3.

In accordance with Fig. 3, in a capillary (on the glass plate's surface 1) the solidified SSS forms continuous layers 2 and transverse jumpers 4 between them. The cuffs and layers not only separate vapor channels 3 from each other, but also hold the micro volumes 5 of residual non-solidified SSS during drying process.

Analysis of the plane view of this structure (Fig. 4) shows that cuffs (position 4 in Fig. 3) are extended chains of vertical walls of a finite length. Presumably, they arose simultaneously with vapor channels appearing in the capillary and are part of capsules, in which another part of unsolidified SSS retains for certain time.

Fig. 4 demonstrates the transparent walls 1 (cuffs) of partially dehydrated SSS 1 capsules grown from each other. Inside the capsules, there are unsolidified SSS 2 remains. The continuous chain of unsolidified SSS capsules differently oriented in direction and elongation of the capsules suggests that with microwave treatment water temperature increasing in encapsulated SSS leads to appearances of a vapor bubble (bubbles) 4 in the capsule and, accordingly, increasing gas pressure in the capsule. Gas pressure increasing inside the capsule leads to deformation and its shell destruction; that is a reason, in some

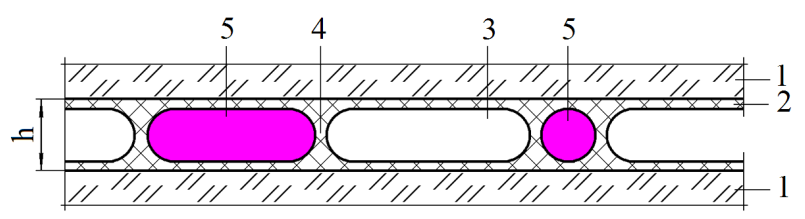

Fig. 3. Scheme of partially solidified SSS in a flat slot-type capillary in side view:

1 - glass plate; 2 - horizontal layer of solidified SSS; 3 - vapor channel (bubble); 4 - vertical sodium silicate cuffs; 5 - unsolidified SSS
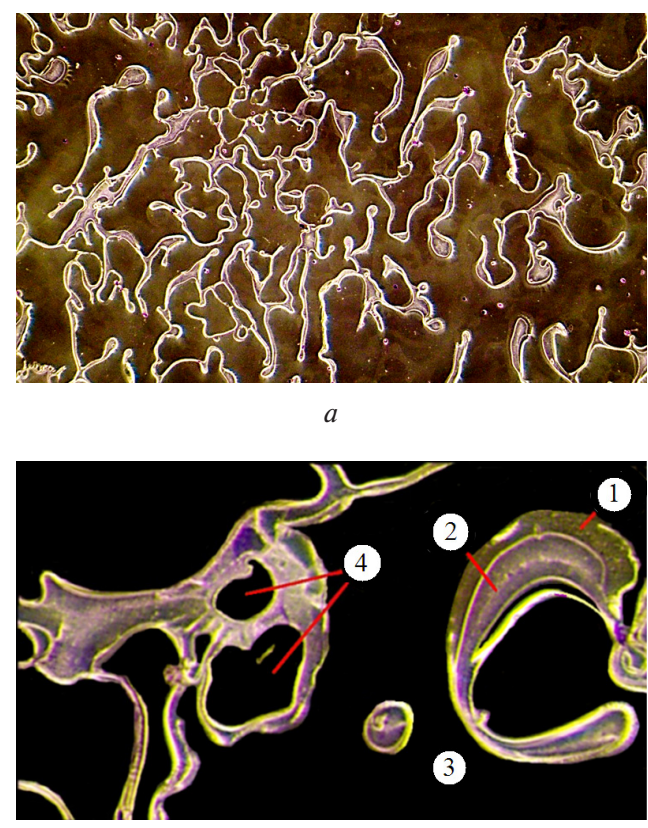

$b$

Fig. 4. Black field appearance of SSS solidified in a flat slottype capillary (plane view) at magnification $\times 14$ (a) and $\times 100(b)$ :

1 - dehydrated sodium silicate; 2 - unsolidified SSS; 3 - vapor channel; 4 - vapor bubble 
cases of forced continuous residual liquid jet outflow from the capsule (Fig. 5, a), in other cases - an instant ("explosive") leftover liquid ejection beyond capsules (Fig. 5, b).

In any case, SSS movement beyond the initial capsule is accompanied by its intense surface dehydration. As a result of dehydration, on the free surface of a moving SSS flow, a continuous elastic shell of partially dehydrated SSS (pyroplastic sodium silicate) is formed. Over time, growth of a vapor bubble in the initial capsule is terminated because of increasing strength of surrounding surface of the bubble shell. Along with these, SSS extrusion from the capsule stops. That is, squeezed SSS from the previous capsule boundaries into vapor channel transforms into a new capsule, and from the old capsule only its retained walls - "cuffs" from sodium silicate remain in the structure.

This process repeats cyclically and continues until there exists at least some free water supplying SSS fluid-moving and its capability for self-encapsulation in the capillary. Moreover, each subsequent emerging capsule of unsolidified SSS will be smaller in volume than its previous capsule. From this it follows that each subsequent vapor bubble of the analyzed structure will have a smaller volume than the one emerging earlier. This means that the SSS substance foamed under the action of microwave radiation in the capillary will always be characterized by a certain gas permeability and unevenness of its bubbles' sizes.

Subsequent heating by microwave radiation is characterized by the fact that the system considered reaches the temperature of $100-103{ }^{\circ} \mathrm{C}$ and by free water complete removal. At further heating (Fig. 6) the water remaining in capsule walls (hydrate water) diffuses inside of pyroplastic cuffs 1 , transfers there in vapor state and destroying, but in some cases even changing the pyroplastic cuffs configuration, emerges through generated cracks 3 in vapor bubbles 2 or steam channels 5 reconfiguring them.

Further SSS processing with microwave radiation does not change its previously formed structure, which, according to Ailer R. (1982) and Nikonov N.S. (1992), is frame polymer $\mathrm{Na}_{2} \mathrm{Si}_{3} \mathrm{O}_{7}$. That is, as a result of going through this multi-stage process, finally dried SSS in a flat capillary (in plan) takes the form shown in Fig. 7, $a$. In the case of SSS drying by MWR in

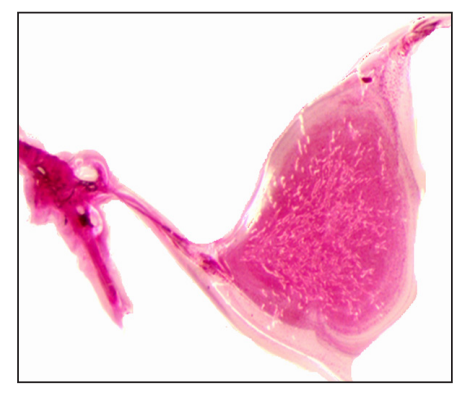

$a$

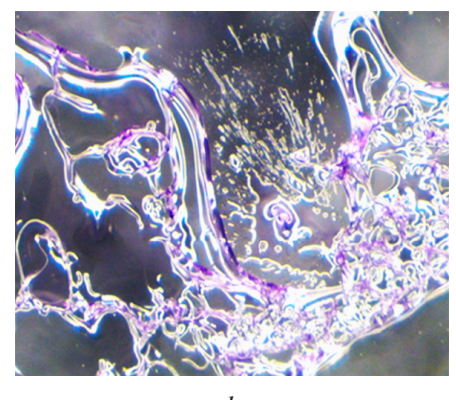

b

Fig. 5. Appearance of SSS solidified in a slot-type capillary formed at jet outflow (a) and "explosive" (b) character of unsolidified SSS releasing from capsules, $\times 100$ a capillary of a greater thickness $(h=400-900 \mu \mathrm{m})$, SSS forms spatial (three-dimensional) foam structures (Fig. 7, b).

Based on the features of the structures obtained, it can be stated that the principle of SSS mass transfer in a flat slot-type capillary and, accordingly, capillary-porous medium under microwave radiation influence is similar to its rapid external heating (thermal "shock") action and is caused by foaming of SSS. However, the foaming mechanisms, as well as properties of formed SSS foam, are different under external thermal shock and under MWR influence.

In particular, SSS mass transfer mechanism under microwave radiation action is characterized by multi-staging and proceeds according to the chain reaction principle. This regularity, apparently, is due to selective microwave radiation heating rate of SSS components [14] and in general can be represented by scheme in Fig. 8.

At the first stage of heating (Fig. 8,a), thin viscous-plastic continuous film (shell) of partially dehydrated (pyroplastic) sodium silicate 2 appears on a SSS drop's free surface 1 as a result of free water evaporation. At the same time, residual unsolidified SSS in a droplet appears to be closed (encapsulated) inside this shell (Fig. 8, $b$ ).

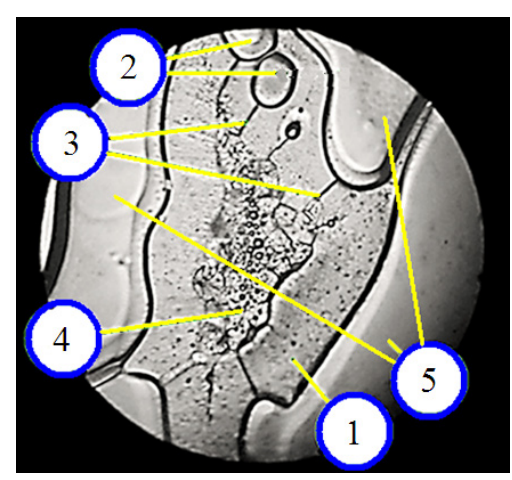

Fig. 6. Structure of the SSS partially solidified in a flat slottype capillary $(\times 200)$ :

1 - pyroplastic sodium silicate cuff; 2 - vapor bubble; 3 - crack; 4 - unsolidified SSS; 5 - steam channel

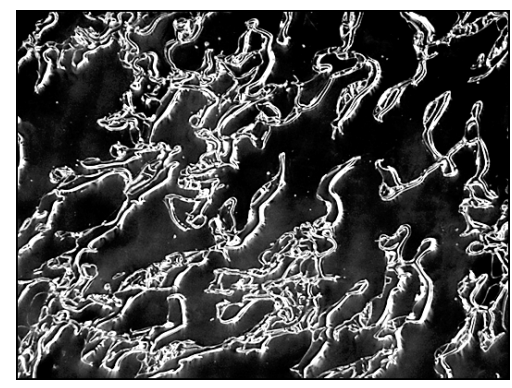

$a$

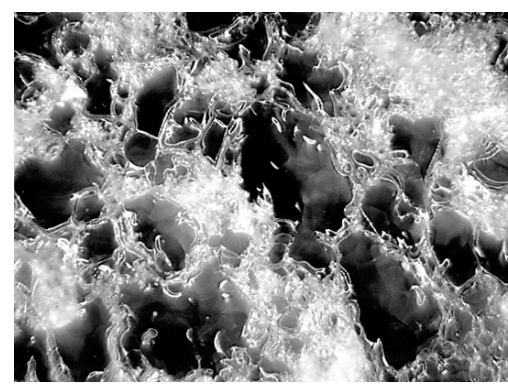

Fig. 7. Section view of the SSS layer in a flat slot-type capillary at $h=40 \mu \mathrm{m}$ (a) and $h=900 \mu \mathrm{m}$ (b) after $90 \mathrm{sec}$ processing with microwave radiation $(\times 75)$ 

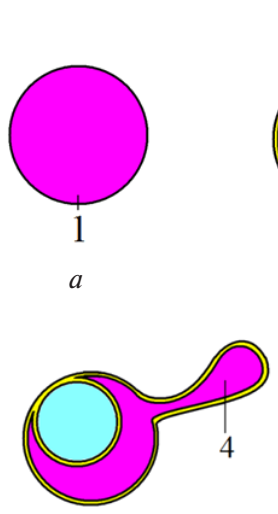

$d$

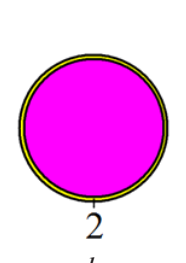

b

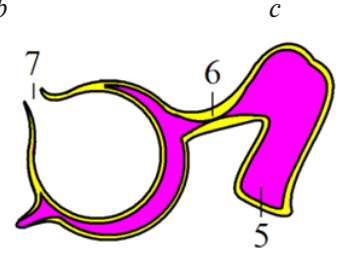

$e$

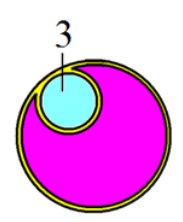

Fig. 8. SSS droplet is formed in a flat slot-type capillary before being exposed to microwave radiation (a), at the initial time of microwave radiation exposure (b), at the time of steam bubble occurring in a droplet (c), at the time of SSS neoplasms occurrence (d), at the time of completion of SSS secondary capsule formation (e):

1 - SSS droplet; 2 - pyroplastic sodium silicate shell (SSS primary capsule); 3 - steam bubble; 4 - SSS neoplasm; 5 - SSS secondary capsule; 6 - inter-capsules channel; 7 - steam channel

At the second stage of heating (Fig. 8, c), upon reaching the boiling point of water, gas bubble 3 appears in a drop of non-solidified SSS.

The third stage of heating (Fig. 8, $d$ ) results in increasing mass of evaporated water in the initial SSS capsule and, accordingly, increasing pressure in both the vapor bubble and the capsule. At certain point in time, when the rate of vapor pressure increasing in the capsule exceeds ultimate deformation of its shell's ability, the shell ruptures and unsolidified SSS extrudes beyond its boundaries. As a result of this release, SSS neoplasm appears 4 . The process of SSS displacing from the initial capsule 4 will continue until increased pressure remains in it (until pyroplastic shell breakthrough and steam outlet from the capsule through the steam channel 6) or unsolidified SSS supply runs out.

At the fourth stage of heating (Figs. 8, $d, e$ ), surface of an SSS jet displaced from the initial capsule is covered with a similar shell, a secondary capsule is formed, while an intercapsules channel 6 between the old and new capsules 5 solidifies completing the process of new encapsulation of displaced SSS. Subsequently, in a new capsule, as in the previous one, a vapor bubble 3 appears. Again, vapor pressure in capsule rises and unsolidified SSS extrudes by jets outside the capsule, forming new capsules and inter-capsules 6 and steam 7 channels (Fig. 8,e).

The data on degrees of SSS drying show that using microwave radiation for sodium silicate solute with a value of silicate modulus of 2.8 to 3.0 drying, allows almost completely dehydrating it in a relatively small period of time (residual moisture content is less than $0.1 \% \mathrm{wt}$.) with increasing its temperature up to $150{ }^{\circ} \mathrm{C}$ instead of $600{ }^{\circ} \mathrm{C}$ as per traditional technology of foaming SSS heating.

Considering the foaming mechanism and SSS mass transferring in a flat slot-type capillary, we should note that vapor pressure in capsules, apparently, can reach significant values. Indirect evidence for this assumption could be results of the following experiments. A drop of water (water mass of about $0.1 \mathrm{~g}$ ) was placed between two flat glasses with dimensions of $120 \times 80 \mathrm{~mm}$ and thickness of $2.2 \mathrm{~mm}$. The glasses in horizontal position were placed in the furnace and treated with microwave radiation for 2 minutes. As a result of the microwave treatment in the initial period of microwave exposure, the water between glasses was heated and transformed into a vapor state and moved to the edges of the glasses being in vapor condition. At a certain distance from the original drop position between the glasses vapor was condensed. Resulting condensate formed a solid annular barrier impervious for the generated steam, which not only fastened initially unfixed glasses together, but also contributed to increasing steam pressure between them. As a result, in the process of continuous microwave heating, the glasses were destroyed. While glasses destruction was accompanied by a sharp short sound that indicates explosive nature of their ruining under the action of the internal water, vapor pressure was formed in the gap between them.

SSS porization and dehydration under microwave radiation action are quickly passing processes taking place simultaneously in a flat slot-type capillary that last from 50 to $70 \mathrm{sec}-$ onds. In this case, formed sodium silicate is situated at the distance by 5-10 times greater than SSS droplets' diameter used in original.

In case of SSS distribution in capillary-porous media, for example quartz sand, sodium silicate extends to 1-2 diameters' distance of original drops of SSS used. Reason for this is SSS bubble destruction during their moving across the capillary channels. However, this SSS transfer in capillary-porous media mechanism can be successfully used, for example, for gluing of mold elements between each other, molds and rods, complex configuration rods, molds and cores repairing. In particular, putting certain amount of sodium silicate solute on the rods' surfaces, connecting them together and processing by microwave radiation for $2-3$ minutes, allows obtaining adhesive seam between rod bonded parts, whose strength will exceed the tensile strength of the rods' structured material. It is important that bonding material for gluing rods between each other should be SSS as well. As practice implies, for sand-sodium-silicate molds and cores bonding, it is advisable to apply SSS with density of $1.42-1.52 \mathrm{~g} / \mathrm{cm}^{3}$ and silicate modulus amount of 2.8-3.0. In these cases, molds and cores gluing surfaces should be SSS covered by a dropper or soft brush. To ensure gluing seam strength, microwave radiation processing of adhesive joint is recommended to realize no later than 1 minute after the application of SSS on the surfaces.

Practical value. Under microwave radiation influence, a stable foam structure is formed with a certain gas permeability and multiplicity of more than 40 in dried sodium SSS. This circumstance together with short duration and selective heating inherent for microwave drying, allows considering this foaming technology as most effective and promising from the point of view of developing new methods and approaches in solving the problem of reducing energy consumption when obtaining fine dispersed dehydrated sodium silicates and structuring granular materials, particularly, foundry molds and cores production.

Conclusions.

1. Description of mass transfer of a sodium silicate solute mechanism in a flat slot-type capillary during microwave radiation heating has been developed. According to this mechanism, SSS mass transfer in the capillary occurs as a result of repeating multiple stages. These stages include SSS encapsulation; increasing vapor pressure in a capsule; ejection of unsolidified SSS out of the capsules; movement of SSS flow ejected out of the capsule being stopped; its encapsulation and so on until water removal from treated sodium silicate solute is completed.

2. Staging of foam structure formation in sodium silicate solute under microwave radiation influence is the reason for significant unevenness of its pores' sizes and availability of certain gas permeability in SSS foam.

3. Sodium SSS drying with silicate modulus from 2.8 to 3.0 by microwave radiation allows reducing water content in dried sodium silicate solute to $0.1 \%$ (wt.) at its temperature increasing to $150{ }^{\circ} \mathrm{C}$.

\section{References.}

1. Abdrakhimov, V.Z., Abdrakhimov, E.S., \& Abdrakhimov, I. D. (2017). Getting insulating material based in liquid 
glass and coal conversion wastes generated during coking coal preparation. Ugol - Russian Coal Journal, 4, 64-67. https:// doi.org/10.18796/0041-5790-2017-4-64-67.

2. Siqian Zhang, Yu-Ri Lee, Whan Ahn, \& Wha-Seung Ahn (2018). Sodium silicate insulating foam reinforced with acidtreated fly ash. Materials Letters, 218(1), 56-59. https://doi. org/10.1016/j.matlet.2018.01.150.

3. Abdrakhimov, E.S. (2019). Use of waste fuel and energy complex - burned rocks and tailings of chromite ore in the production of porous aggregate on the basis of liquid-glass compositions. Ugol - Russian Coal Journal, 7, 67-69. https:// doi.org/10.18796/0041-5790-2019-7-67-69.

4. Kogan, V.E. (2016). Inorganic and organic vitreous foam materials and prospect of environmental cleaning from oil and oil products pollutions. Journal of Miming Institute, 218, 331337. ISSN 0135-3500.

5. Romero, A. R., Toniolo, N., Boccaccini, A. R., \& Bernardo, E. (2019). Glass-Ceramic Foams from «Weak Alkali Activation» and Gel-Casting of Waste Glass. Fly Ash Mixtures. Materials, 12(588), 1-14. https://doi.org/10.3390/ma12040588.

6. Wattanasiriwech, D., Nontachit, S., Manomaivibool, P., \& Wattanasiriwech, S. (2019). Foam glass from municipal waste as a lightweight aggregate for cement mortar. IOP Conferens Series: Earth and Environmental Science, 351, 1-6. https://doi. org/10.1088/1755-1315/351/1/012008.

7. Paunescu, L., Dragoescu, M.F., Axinte, S.M., \& Sebez, A.C. (2019). Nonconventional technique for producing high mechanical strength glass foam from glass waste. Journal of Engineering Studies and Research, 2, 48-55. https://doi. org/10.29081/jesr.v25i2.320.

8. García-Moreno, F. (2016). Commercial Applications of Metal Foams: Their Properties and Production. Materials, 9(85), 2-27. https://doi.org/10.3390/ma9020085.

9. Ye Li, Xudong Cheng, Wei Cao, Lunlun Gong, Ruifang Zhang, \& Heping Zhang (2016). Development of adiabatic foam using sodium silicate modified by boric acid. Journal of Alloys and Compounds, 666, 513-519. https://doi.org/10.1016/i. jallcom.2016.01.139.

10. Gilyazidinova, N., Rudkovskaya, N., \& Santalova, T. (2018). Nature conservation technology for producing slagfoam glass as a structural and thermal insulating material. E3S Web of Conferences, III I International Innovative Mining Symposium, 41, 1-7. https://doi.org/10.1051/e3sconf/20184102017. 11. Zhigulina, A., \& Mizuriaev, S. (2017).Technology of obtaining thermal insulation material on the basis of liquid glass by a method of low temperature processing. MATEC Web of Conferences, Theoretical Foundation of Civil Engineering, 117, 1-7. https://doi.org/10.1051/matecconf/20171170018.

12. Tkachenko, S.S., Kolodiy, G.A., Znamensky, L. G., \& Ermolenko, A.A. (2018). Cold mixture of inorganic binder: status and prospects of development (inorganic vs. organic). Foundry production and metallurgy, 2(91), 16-22. https:// doi.org/10.21122/1683-6065-2018-2-16-22.

13. Solonenko, L., Prokopovich, I., Repyakh, S., Sukhoi, K., \& Dmytrenko, D. (2019). System analysis of modern areas of increasing environmental and sanitary hygienic safety of using cold hardening mixtures in foundry. Odessa Polytechnic University, Proceedings, 1(57), 90-98. ISSN 2076-2429.

14. Solonenko, L. I., Bilyi, O.P., Repiakh, S. I., Kimstach, T. V., \& Uzlov, K. I. (2020). Heating rate of granular inorganic materials by microwave radiation. Naukovyi Visnyk Natsionalnoho Hirnychoho Universytetu, (2), 37-41. https:// doi.org/10.33271/nvngu/2020-2/037.

\section{Спінювання рідкого скла у плоскому капілярі щілинного типу під дією мікрохвильового випромінювання}

\author{
Л. І. Солоненко ${ }^{1}$, Р. В. Усенко ${ }^{2}$, А. В. Дзюбіна ${ }^{2}$, \\ K. I. Узлов ${ }^{2}$, C.I.Pen' $я x^{2}$
}

1 - Одеський національний політехнічний університет, м. Одеса, Україна

2 - Національна металургійна академія України, м. Дніпро, Україна, e-mail: 123rs@ua.fm

Мета. Встановлення механізму масопереносу при спінюванні рідкого скла у плоскому капілярі щілинного типу під дією мікрохвильового випромінювання

Методика. У дослідженнях використовували содове рідке скло з силікатним модулем 2,8-3,0 і питомою щіль-

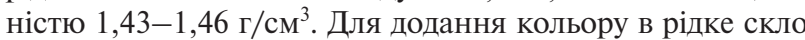
вводили чорнило червоного кольору. Обробку водних розчинів рідкого скла мікрохвильовим випромінюванням проводили в печі з об'ємом робочої камери 23 літра, при номінальній потужності магнетрону 700 Вт і частотою випромінювання 2450 МГц. Дослідження структури спіненого рідкого скла проводили на оптичному мікроскопі зі збільшенням від 25 до 200 крат. Температуру в мікрохвильовій печі вимірювали за допомогою безконтактного електронного інфрачервоного термометра Temperature AR 320. Визначення маси проводили на електронних вагах із точністю 0,01 г. Спінювання рідкого скла здійснювали у плоскому капілярі щілинного типу товщиною від 30 до 900 мкм, утвореним двома паралельно розташованими один до одному скляними пластинами.

Результати. Визначено механізм масопереносу рідкого скла при його спінюванні у плоскому капілярі щілинного типу при нагріванні мікрохвильовим випромінюванням. Встановлено, що перенос рідкого скла в капілярі проходить поетапно за схемою, подібною проходженню ланцюгової реакції. Схема включає: самокапсулювання рідкого скла, обумовлене виникненням на ії вільній поверхні оболонки із частково дегідратованого рідкого скла, поява в капсулі парової бульбашки, підвищення парового тиску в капсулі, руйнування оболонки капсули й викид за межі капсули здебільшого незатверділого в ній рідкого скла, повне видалення рідкого скла з капсули та іiі руйнування під дією підвищеного парового тиску, припинення руху потоку викинутого за межі капсули рідкого скла, його повторне самокапсулювання й т.п. Цей процес повторюється до повного видалення води з оброблюваного рідкого скла. Етапність і певна циклічність виникнення пінної структури в рідкому склі під дією мікрохвильового випромінювання є основною причиною суттєвої нерівномірності дисперсності іiі пір і газопроникності піни, що утворилася.

Наукова новизна. Уперше розроблено опис механізму масопереносу рідкого скла при його спінюванні у плоскому капілярі щілинного типу при нагріванні мікрохвильовим випромінюванням. Уперше визначено, що обробка натрієвого рідкого скла з силікатним модулем від 2,8 до 3,0 мікрохвильовим випромінюванням дозволяє зменшити вміст води у висушеному рідкому склі до змісту менше $0,1 \%$ по масі.

Практична значимість. Спінювання рідкого скла мікрохвильовим випромінюванням $є$ перспективним процесом з точки зору розробки нових способів і підходів у вирішенні проблеми оптимізації структурування зернистих матеріалів i, зокрема, для виробництва піщаних ливарних форм і стрижнів.

Ключові слова: масопереніс, пар, рідке скло, вода, капіляр, капсула, спінювання, мікрохвильове випромінювання

\section{Вспенивание жидкого стекла в плоском капилляре щелевого типа под действием микроволнового излучения}

\author{
Л. И. Солоненко ${ }^{1}$, Р. В. Усенко ${ }^{2}$, А. В. Дзюбина ${ }^{2}$, \\ К. И. Узлов ${ }^{2}$ С. И. Репях ${ }^{2}$
}


1 - Одесский национальный политехнический университет, г. Одесса, Украина

2 - Национальная металлургическая академия Украины, г. Днепр, Украина, e-mail: 123rs@ua.fm

Цель. Установление механизма массопереноса при вспенивании жидкого стекла в плоском капилляре щелевого типа под действием микроволнового излучения

Методика. В исследованиях использовали содовое натриевое жидкое стекло с силикатным модулем 2,8-3,0

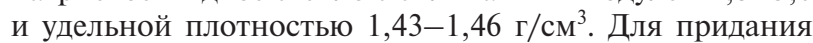
цвета в жидкое стекло вводили чернила красного цвета. Обработку водных растворов жидкого стекла микроволновым излучением проводили в печи с объёмом рабочей камеры 23 литра, при номинальной мощности магнетрона 700 Вт и частоте излучения 2450 МГц. Исследование структуры вспененного жидкого стекла проводили на оптическом микроскопе с увеличением от 25 до 200 крат. Температуру в микроволновой печи измеряли с помощью бесконтактного электронного инфракрасного термометра Temperature AR 320. Определение массы проводили на электронных весах с точностью 0,01 г. Вспенивание жидкого стекла осуществляли в плоском капилляре щелевого типа толщиной от 30 до 900 мкм, образованном двумя параллельно расположенными друг к другу стеклянными пластинами.

Результаты. Определен механизм массопереноса жидкого стекла при его вспенивании в плоском капилляре щелевого типа при нагреве микроволновым излучением. Установлено, что перенос жидкого стекла в капилляре проходит поэтапно по схеме, подобной прохождению цепной реакции. Схема включает: самокапсулирование жидкого стекла, обусловленное возникновением на её свободной поверхности оболочки из частично дегидратированного жидкого стекла, появление в капсуле парового пузырька, повышение парового давления в капсуле, разрушение оболочки капсулы и выброс за пределы капсулы части не затвердевшего в ней жидкого стекла, пол- ное удаление жидкого стекла из капсулы и её разрушение под действием повышенного парового давления, прекращение движения потока выброшенного за пределы капсулы жидкого стекла, его повторное самокапсулирование и т.д. Этот процесс повторяется до полного удаления воды из обрабатываемого жидкого стекла. Этапность и определённая цикличность образования пенной структуры в жидком стекле под действием микроволнового излучения является основной причиной существенной неравномерности дисперсности её пор и газопроницаемости образующейся пены.

Научная новизна. Впервые разработано описание механизма массопереноса жидкого стекла при его вспенивании в плоском капилляре щелевого типа при нагреве микроволновым излучением. Впервые определено, что обработка натриевого жидкого стекла с силикатным модулем от 2,8 до 3,0 микроволновым излучением позволяет уменьшить содержание воды в высушенном жидком стекле до содержания менее $0,1 \%$ по массе.

Практическая значимость. Вспенивание жидкого стекла микроволновым излучением является перспективным процессом с точки зрения разработки новых способов и подходов в решении проблемы оптимизации структурирования зернистых материалов и, в частности, для производства литейных форм и стержней. Знание механизма вспенивания жидкого стекла позволит повысить точность прогнозирования структуры и свойств пеноматериалов, изготавливаемых на основе жидкого стекла, оптимизировать параметры процесса их поризации, расширить представления о технологических возможностях использования жидких стёкол в структурировании пористых сред, их обезвоживания микроволновым излучением и т. п.

Ключевые слова: массоперенос, пар, жидкое стекло, вода, капилляр, капсула, вспенивание, микроволновое излучение

Recommended for publication by V. Yu. Seliverstov, Doctor of Technical Sciences. The manuscript was submitted 11.03.20. 